\title{
Woman Stereotypes and Patriarchal Hegemony: A Feminist Stylistics Analysis of Iraqi Folk Proverbs
}

\author{
Asst.Prof.Dr. Nassier A. G. Al-Zubaidi \\ University of Baghdad \\ College of Arts \\ nassieralzubaidi@gmail.com
}

\section{Received: 8/12/2018 \\ Accepted:22/1/2019}

\begin{abstract}
The present research examines the stereotypical representations of women and women's position in the discourse practices of Iraqi folk proverbs from a feminist stylistics perspective. Sara Mills' (2008) theoretical framework is adopted to analyze a sample of 315 proverbs drawn from written and oral sources. The analysis reveals that the sub-categories of woman in general and wife in particular are the most frequently targeted in Iraqi proverbs. Personal attributes are the most salient properties associated with Iraqi women compared to physical attributes. Women are generally represented negatively in the Iraqi proverbial discourse where proverbs are generally manipulated to disparage and denigrate women. The traditional ideals of hegemonic masculinity, patriarchal ideology and gender inequality are encoded in the discourse of these proverbs. That is, the institutionalization of male domination and the secondary position of women are grounded in the structure of Iraqi society. Finally, a number of conclusions are presented.
\end{abstract}

Key Words: woman stereotypes, hegemonic masculinity, gender inequality, Iraqi proverbs.

\section{نمطية المرأة و التسلط الذكوري: تحليل نسوي أسلوبي للأمثال الثعبية العراقية

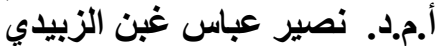 جامعة بغداد كلية الاداب الرباب}

تتقصى هذه الدراسة التمثلات النمطية للمر أة ومكانتها في الممارسات النصية للأمثال الثعبية العراقية

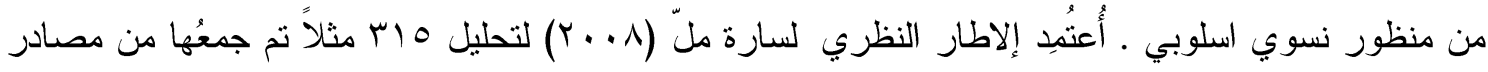

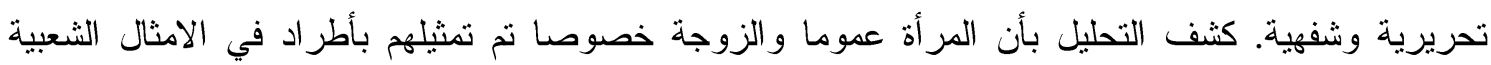
العر اقية. ووجد أن الصفات الثخصية المعنوية التي ترتبط بالمرأة العر اقية اكثرمن الصفات الشخصية المادية.

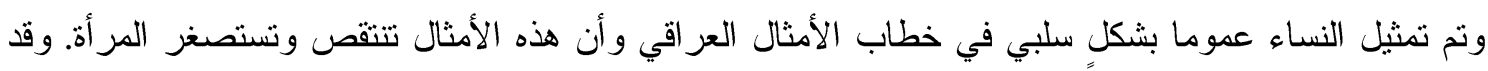

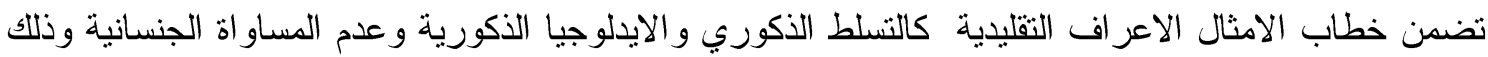
يعزى الى شيوع التسلط الذكوري و الدور الثانوي للمرأة في التركيب المجتمي العر اقي. وختاما تم تقديم عدد

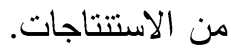
الكلمات المفتاحية: الصورة النمطية للمر أة- التسلط الذكوري-عدم المساو اة الجنسانيةـ الامثال العر اقية 


\section{Introduction}

Stereotypes are a type of mental categories or schemata which interpret and reflect reality. They are "socially-constructed mental pigeon-holes into which events and individuals can be sorted, thereby making such events and individuals comprehensible" (Fowler, 1991:33). For Cameron (2008: 21), "to stereotype someone is to interpret their behavior, personality and so on in terms of a set of common-sense attributions which are applied to whole groups.". Stereotypes associated with people are frequently observed in various social practices like folk jokes, folk literature, press, movies, social media, etc.

More specifically, gender stereotyping is a universal phenomenon that exists in every culture, yet the distinct stereotyping properties and attributes vary from one culture to another. It is generally based on categorizing human beings on the basis of biological sex. Basow (1992:2) maintains that gender stereotyping is oversimplification, exaggeration, generalization and reduction of man and woman's roles in a society. By means of which, men and women are categorized differently and ascribed different attributes, for example, women more likely to gossip than men, or women see more color gradations than men. In this respect, Talbot (2010:472) remarks that "gender stereotypes are linked to gender ideology to reproduce naturalized gender differences. In doing so, they function to sustain hegemonic male dominance and female subordination". Hence it is not surprising to find out that men are always designated positive attributes whereas women are designated neutral or negative ones. While positive stereotypes are not problematic, negative ones create prejudice and shape a powerful and lasting male-biased group mentality (Reutler, 2013).

In most Arabic-speaking countries, women have been described for a long time in terms of a set of biased-gender stereotypes like women tend to be too emotional, too weak, too wicked, impatient, and submissive compared to men (Sadiqi, 2003:123). This conception assists in perpetuating the traditional roles of woman as a housewife, a daughter, etc., and they are presented as the natural and normal ones. Relatedly, Fairclough (1989: 77) remarks that "conventions routinely drawn upon in discourse embody ideological assumptions which come to be taken as mere "common sense" and which contribute to sustaining existing power relations".

The encoding of gender in discourse has recently attracted a great deal of research interest among feminist linguists (cf. Talbot, 1998; Sunderland, 2006; Cameron, 2008; Mills, 2008 among others). Their research focuses on Western middle-class women taking either one of the two main tracks; gender differences in terms of language use and the representation of gender in discourse. Due to the dearth of research on the representation of Middle Eastern women in discourse, the present research takes the second investigation track to explore linguistic gender stereotyping of Arab women as delineated in Iraqi women. More precisely, it discerns how woman stereotypes are portrayed in the discourse mode of Iraqi folk proverbs to foster gender inequality and masculine hegemony. 
Such kind of research is relevant for several reasons. Findings would help in a better understanding of the image of women in the proverbial discourse of a linguistic and cultural context not examined before. Besides, studies of different patterns of speech behavior in a variety of languages and cultures would provide a solid basis for badly needed cross linguistic/cultural analysis; research which would greatly aid in efforts toward intercultural communication. The study of speech as a cultural phenomenon and its role in cultural identity has shown that different communities vary in their production and interpretation of linguistic behaviors.

\section{Proverbs and woman stereotypes}

Proverbs are linguistic adages and precepts which are the product of societies' experiences and observations. They do exist in all societies as part of their linguistic and cultural heritages, and language speakers bequeath them to their offspring through the generations. Being transmitters and reflectors of accumulated wisdom, they are generally accepted blindly; and are a manifestation of the traditional values of a society. In the context of gender and language relationships, proverbs acquire a great research interest as they mirror the traditional unequal distribution of power between genders (Stone, 2006). Due to the fact that proverbs are a reflective archetype of their societies, scholars show an increasing investigation interest in exploring the extent to which the beliefs, perceptions and expectations of societies are reflected on the discourse practices of proverbs examining their gendered discourse.

Following Belfatmi (2013:15), the interest for considering the analysis of women stereotypes in proverbs is justified by a number of motivations; "first, proverbs are part of people's everyday life and express collective wisdom and truth; second, knowing that proverbs are fading away gradually in most societies motivates one to revive some of these proverbs but at the same time shed some light on gender discrimination that most proverbs discuss; and finally, it is believed that there is a an urgent need to highlight some misconceptions of those gendered proverbs, therefore people's awareness not only will be raised but they will pay a great attention when using proverbs that are based on gender biases which spread some false truths and behaviours" .

One of the main principles of the social perspective of discourse is that discourse is both a mode of representation and a mode of action (Fairclough, 1992). Sadiqi (2003:145) notes that "the importance of discourse in understanding the role of genderrelated meanings can be lucidly revealed in proverbs. Their rhyming structure makes them easy to remember, their construction on a paradox appeals to the ear, their ideologically-laden messages cannot be easily contested by their users, and the 'takenfor-granted' truths they express are believed to embody the wisdom of previous generations and are, hence, considered a valuable legacy and a permanent source of advice, in a society that venerates its past".

Kerschen (2012:3) confirms the idea that in order to expose gender inequality and male chauvinism, proverbs are perhaps the best indicators of attitudes and beliefs. And 
if one wants to explore the historical image of women in oral tradition, proverbs are an ideal subject. Proverbs of all societies are replete with commentary on the nature of women and the relationship of women to one another and to other beings and objects . Kerschen further maintains that "generally speaking, proverbs about women are characterized by biting wit and bitter complaints. While some proverbs are the saccharine, the majority portray woman as a sharp-tongued, long-winded, emptyheaded, toy-like creature who is faithless to the man by whom she should be ruled and to whom she belongs like property or livestock" (ibid: 8 ).

To date studies have explored the representation of woman and the construction of gender relations in proverbs across different languages and cultures (cf. Lee, 2015 on Chinese proverbs; Sanauddin, 2015 on Pashtun proverbs; Nakhavaly \& Sharifi, 2013 on Persian proverbs; Kerschen, 2012 on American proverbs; Andersson, 2012 on Sweden proverbs; Hussein, 2009 on African proverbs among others). Findings from most of research investigations report the inferiority of women and their negative representation in the proverbs of these different languages and cultures. As far as research on Arabic discourse and gender identity is concerned, research shows that Arabic is an androcentric language in its nature, and its discourse exhibits various types of overt linguistic sexism imposing a structural limitation on the derogatory status of woman (cf. Nayef \& El-Nashar, 2014, 2015; El-Falaky, 2015). This finding needs further supporting evidence, and one of the aims of the current research is to reexamine this strong claim. After a careful inspection of previous research, it is found that no study has been conducted on gender stereotypes and Iraqi proverbial discourse. Therefore, the present research dedicates itself to investigate the representation of woman in Iraqi folk proverbs and to explore to what extent Iraqi Arabic is linguistically androcentric.

\section{Research objectives and questions}

This research is devoted to examine how the discourse of Iraqi folk proverbs plays a role in constructing the woman's identity. It aims at exploring the relationship between the discourse of Iraqi folk proverbs and gender stereotypes. Accordingly, it sets out to answer the following research questions:

1. What are the main categories of women portrayed in the discourse of Iraqi folk proverbs?

2. What is the kind of attributes assigned to women in the discourse of Iraqi folk proverbs?

3. What is the kind of women's image represented in the discourse of Iraqi folk proverbs?

4. How do gender inequality and patriarchal hegemony in the Iraqi proverbial discourse reflect the socio-cultural perceptions and practices relating to gender relations in the community in question? 


\section{Research methodology}

The current research is a feminist stylistics analysis of Iraqi gendered proverbs to uncover how power relationships of different genders are determined through linguistic choices in a language and society not explored before. To answer the research questions, the research adopts qualitative and quantitative methods of analysis to examine how woman is perceived, symbolized and portrayed through Iraqi folk proverbs. In other words, a qualitative content analysis of every single proverb followed by a quantitative analysis for the entire data are run with the exception of question four where a qualitative content analysis of selected proverbs is conducted to examine how the Iraqi socio-cultural context is reflected on the woman's image in the sample proverbs.

\subsection{Data collection and sampling}

To collect a representative sample of proverbs for the current research, two kinds of data collection are used. These are collection of proverbs from pre-existing written sources and from local Iraqi informants. The proverbs about gender stereotypes are selected from four published collections of Iraqi folk proverbs. The collections consulted are Al-Dabag (1956), Al-Hanefi (1962), Al-Dileishi (1972) and Al-Tikriti (1986). The four published collections of proverbs are widely consulted as the main written and documented sources of Iraqi folk proverbs. They are relatively comprehensive and cover different geographical regions of Iraq (i.e., the southern, northern and central part of Iraq). They are carefully inspected and a total of 285 proverbs on woman stereotypes are selected. The majority of proverbs are found in these collections. The research has also collected about 30 new proverbs through fieldworks and interviews with local informants. These proverbs are not documented in any previously published collection. The total number of proverbs collected from the two kinds of data sources is 315 . Only proverbs that explicitly refer to female gender are considered for analysis. Thus, all the proverbs about a female/ females, wherein words such as woman, girl, lady, maid, etc. personal names and pronouns such as she or her as a reference to a female, are included in the data analysis.

\subsection{Analysis procedures}

Gendered proverbs collected are categorized and analyzed according to their semantic proposition. They are undergone a meticulous content analysis. To fully understand proverbs as a meaningful discourse, the historical and socio-cultural contexts of proverbs need to be considered (Paltridge, 1994). So, Iraqi socio-cultural and historical contexts are taken into account and proverbial discourse is examined within these contexts. Iraqi folk proverbs cited are translated into English. The sociocultural aspects of Iraqi proverbs make their translation relatively difficult. However, from the literal translation, an actual translation is undertaken. Each proverb is provided first in the source language (Iraqi Arabic), then in the target language (English). No transliteration is used in writing the proverbs cited. After this, proverbs 
are divided into categories according to the themes and images exemplified through them. Due to space constraints, complete and full interpretation and discussion of all proverbs cited is abandoned.

\section{3 Conceptual framework and analysis tools}

To investigate how woman stereotypes are portrayed in Iraqi proverbial discourse, the data is analyzed within a feminist stylistics framework proposed by Sara Mills (2008). Feminist stylistics intends to examine the language of texts to answer questions asked particularly within a feminist perspective. It is defined as "a form of politically motivated stylistics whose aim is to develop an awareness of the way gender is handled in texts. Feminist stylistics tends to unmask ideologies which seem to be hidden within language-use which poses itself as natural" (Mills, 1995:207).

Mills (2008) distinguishes between two forms of linguistic sexism, namely, overt sexism and covert sexism. The former is the use of any clear and unambiguous utterance that refers directly to women in any negative way as in the use of generic pronouns, naming, androcentrism, similes, etc. The latter, on the other hand, has the same effect but indirectly in that it is only understood contextually and in relation to the surrounding utterances as in the use of collocations, transitivity, visibility, etc. Moreover, Mills $(1995,2008)$ formulates a comprehensive "toolkit" that can reveal the representations of woman in literary and non-literary texts. The "toolkit" consists of three levels of linguistic analysis. That is, any text can be analyzed at the levels of the word, phrase/sentence, and discourse. This enables researchers to make a meticulous investigation of dominant and recurrent linguistic features of a given text to reveal gendered ideologies.

For Mills (2008), the word level of analysis focuses on gender bias that can be observed in the use of individual words or lexical items. She refers to sexism in language as the basis for examining word choices. Word choices can be investigated by examining the occurrences of sex-specific pronouns, generic pronouns, naming, semantic derogation metaphors, etc. The phrases/sentences level of analysis, on the other hand, includes ready-made phrases, presupposition and inference, jokes or humor, transitivity choices, etc. In examining phrases or sentences of a given text, it is possible to unravel features that are significantly gender-biased. Finally, the discourse level of analysis covers an extended analysis beyond the sentence level. Mills maintains that discursive practices can be gender-biased. She believes that discourse is profoundly gendered, and tries to show that discourse, words and phrases work altogether to expose gender ideologies. Discourse categories can be one of the following practices like characterization, fragmentation, focalization, and schemata.

It is worthy noted that the linguistic categories employed in the analysis of the research data are taken from Mills' (2008) analytic toolkits. For answering the first research question about the category type of women portrayed in Iraqi folk proverbs, lexical nominals and pronominals are examined. They include a set of nouns, personal 
names, and pronouns (e.g., woman, aunt, grandmother, she, etc.) used to designate the targeted female identities in the present data of proverbs.

In order to find a reliable answer to question two about the kind of attributes assigned to women in Iraqi folk proverbs, lexical collocations of nouns and adjectives along with their connotations used to describe females in Iraqi proverbs are investigated.

To answer question three about the kind of women's image represented in Iraqi folk proverbs, connotations of lexical nouns and adjectives, verbal choices, presuppositions, implicatures and figures of speech are examined here. Finally, question four is answered via running a qualitative content analysis of sample proverbs to explicate how Iraqi socio-cultural practices and assumptions are mirrored on the selected data of sexiest proverbs.

\section{Findings and discussion}

The data are tested qualitatively and quantitatively to answer the research questions and draw an image of how Iraqi women are portrayed in the proverbial discourse. The results of analysis are presented and discussed in the following sub-sections.

\subsection{Categories of women: Generic vs. specific}

The data are classified under two major categories; generic and specific sexiest proverbs to find out whether women in general are being the target of Iraqi proverbs or is there a specific category of women which is more targeted in these proverbs? The category of generic sexist proverbs covers proverbs that refer to women in general roles. It includes sub-categories like generic woman (e.g., Ma'rah, Hurmah, Hurah Neswan,"Woman/women"), personal names(e.g., Reemah, iFtaimah or Fatmah, Halimah, Diyah, iSa'aidah, iHmidah, iSlaimah), teknonyms (e.g., Um Hussein -"the mother of Hussein", Um Ahmed- "the mother of Ahmed", Um Musa- "the mother of Moses" ) and feminine pronouns(e.g., she, her). The category of specific sexist proverbs, on the other hand, covers proverbs that refer to women in specific roles. It comprises the subcategories of women like mothers, wives, mothers-in-law, daughter, professional roles (e.g., maid, prostitute, pimp, etc.) etc.

The data analysis reveals that the distribution of the generic categories of women exceeds that of the specific categories. More specifically, of the 315 sexiest proverbs under investigation, 182 proverbs fall under the generic category with a $(57.77 \%)$, while only 133 proverbs fall under the specific category with a $(42.23 \%)$. The following are some illustrative examples of the two main categories of proverbs;

1. (Beat a woman before lunch and after dinner)

$$
\text { 1 - 2 - اضرب المرة قبل الغدة وبعد العشة }
$$

This proverb belongs to the generic sexiest category of proverbs. It refers implicitly to certain attributes which are stereotypically associated with women. It depicts that women are trouble-makers, naughty, sharp-tongued and empty-headed, and need to be beaten to stop them. And in this way, men can live a peaceful and quiet life. The 
proverb stresses the patriarchal nature of traditional Iraqi society and the weak status of women in that society.

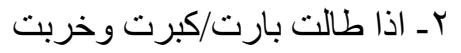

2. (If she stays longer, she is rendered barren.)

The proverb is a generic sexiest proverb. It is associated with the commonly shared view among Iraqi people that women should be early married, otherwise they will be a heavy burden for their parents and families. It is believed that they are weak, and cannot protect themselves by their own. The proverb can be used as a warning for a woman against the procrastination of marriage.

$$
\text { r- لا تبيع سرك لمرتك/ ليبيع سره لمرنه خسر ان }
$$

3. (Do not expose a secret to your wife.)

The proverb is a specific sexiest proverb. It implies that women are not trustworthy in keeping secrets because they get used to spread secrets of their homes. So, it functions as an advice to men of not telling secrets to their wives. There is a widely circulated view in the Iraqi society that women as part of their nature are unable to keep secrets like personal home affairs unlike Iraqi men.

ع - مرة الاب متنحب

4. (The stepmother cannot be liked)

$$
\text { 5- اكله واتعياه ولمرة ابوية ما انطهياه / اكله وزو عهد وما انطي لمرة ابوي }
$$

5. (Eat and vomit it and I would not ever give it to my stepmother)

These two proverbs belong to the specific sexist category. They depict that a stepmother cannot be liked or accepted by her husband's sons and daughters. This view is commonly held among Iraqi people, and very lucidly depicted in the proverbs cited above.

Looking closer at the two main categories, it has been found that the sub-category of generic woman seems to be the most salient target of sexiest proverbs. Women in general are the subject of these proverbs with a $49.45 \%$ (90 proverbs). Wives, on the other hand, tend to be the most dominant target within the category of specific sexiest proverbs. They constitute a $36.09 \%$ (48 proverbs) of the proverbs cited. This finding supports van Dijk's (2001) view that language does not belong to everyone equally and that those in control of this tool determine what and who to be depicted in a favorable light and who to be criticized. Table 1 below displays the distribution of women in terms of generic and specific roles. 
Table 1: Specific category vs. Generic category.

\begin{tabular}{|c|c|c|}
\hline Category of Women & $\begin{array}{c}\text { Sub-Categories of } \\
\text { Women }\end{array}$ & $\begin{array}{l}\text { No. of Occurrences } \\
\text { (No.\& \%) }\end{array}$ \\
\hline $\begin{array}{c}\text { Generic Categories of } \\
\text { Women }\end{array}$ & $\begin{array}{l}\text { Woman, personal names, } \\
\text { teknonymy, and personal } \\
\text { pronouns }\end{array}$ & $\begin{array}{c}\text { IAr } \\
(\% \circ V . V V)\end{array}$ \\
\hline $\begin{array}{c}\text { Specific Categories of } \\
\text { Women }\end{array}$ & $\begin{array}{l}\text { Daughter, sister, girl, } \\
\text { mother, mother-in-law, } \\
\text { daughter-in-law, sister-in- } \\
\text { law, step-mother, wife, } \\
\text { second wife, bride, niece, } \\
\text { divorced, widow, spinster, } \\
\text { aunt, grandmother, old } \\
\text { woman, lady, and } \\
\text { professional roles. }\end{array}$ & $\begin{array}{c}1 r r \\
(42.23 \%)\end{array}$ \\
\hline Total & & $\begin{array}{c}315 \\
(100 \%)\end{array}$ \\
\hline
\end{tabular}

\subsection{Categories of attributes: Physical vs. personal}

The analysis executed here is an attempt to answer the second research question about what is the kind of attributes assigned to women in Iraqi folk proverbs? The proverbs are divided, in terms of the attributes they contain, into two main categories, namely, physical and personal attributes. The binary classification is based on Bemiller and Schneider's (2010) taxonomy of human attributes and characteristics. The data are examined in terms of the most salient features or attributes associated with women in Iraqi folk proverbs. An examination of the sample proverbs reveal that the most prominent personal attributes associated with women include mean, jealous, stupid, foolish, evil, revengeful, domineering, nagging, greedy, demanding, aggressive, weak, naïve, lazy, hard-hearted, irrational, dependent, undetermined, reluctant, submissive, wicked, talkative, meddlesome, kind, loving, caring, hard-working, tidy and bearable. While the physical attributes associated with women contain ugly, fake, tall, short, black, thin, white-skinned and beautiful. Table 2 below presents the distribution of physical and personal attributes associated with women in Iraqi proverbs. 
Table 2: Physical attributes vs. Personal attributes.

\begin{tabular}{|c|c|c|}
\hline Category of Women & $\begin{array}{c}\text { Physical Attributes } \\
\text { (No. \& \%) }\end{array}$ & $\begin{array}{l}\text { Personal Attributes } \\
\text { (No. \& \%) }\end{array}$ \\
\hline $\begin{array}{c}\text { Generic Categories of } \\
\text { Women }\end{array}$ & $\begin{array}{c}r \cdot \\
(48.78 \%)\end{array}$ & $\begin{array}{c}17 r \\
(59.12 \%)\end{array}$ \\
\hline $\begin{array}{c}\text { Specific Categories of } \\
\text { Women }\end{array}$ & $\begin{array}{c}r \\
(51.22 \%)\end{array}$ & $\begin{array}{c}11 r \\
(\mathbf{4 0 . 8 8 \%})\end{array}$ \\
\hline Total & $\begin{array}{c}\varepsilon 1 \\
(13.02 \%)\end{array}$ & $\begin{array}{c}r V \varepsilon \\
(86.98 \%)\end{array}$ \\
\hline
\end{tabular}

The statistical distribution of personal attributes significantly surpasses that of physical attributes. Specifically, the frequency of personal attributes far exceeds the frequency of physical attributes associated with women in both categories of generic and specific sexiest jokes. The former category constitutes $274(86.98 \%)$ out of 315 compared to only $41(13.02 \%)$ of the latter category. The justification for such a significant breach of results between the two categories can be attributed to the conservative nature of Iraqi society. The Iraqi society is constrained by a strict set of socio-religious ethos and perceptions where a woman's body and physical attributes are regarded as a taboo topic. Physical properties of a woman's body cannot be talked about in a public sphere. The same finding has been reported in Nayef \& EL-Nashar's (2014) study. They have found that Egyptian jokes dealing with personal attributes of women far outnumber those dealing with physical features. A possible explanation for this result is that "the Egyptian society is governed by a set of taboos the root of which can be traced to the Islamic oriental ideology and prescriptions. Thus, talking about the physical features of women's body in a joke will hamper its dissemination by others who might feel embarrassed or even ashamed of repeating it. The shock of breaking a taboo, whether by praising or criticizing a women's body, will have an adverse effect on stirring laughter" (p.139). The following are some illustrative examples from the present data;

$$
\text { آ- البنت تمره لا تودّع صديج و لا ينضرب بيها طريجي }
$$

6. (A girl looks like dates which cannot be kept with a friend nor be left alone)

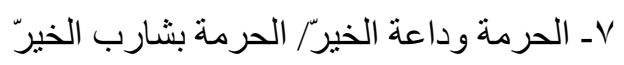

7. (A woman is protected and safeguarded by a man) 
Example 6 is a specific sexiest proverb. It depicts that girls cannot be left alone because they have limited means, and are easily fooled. Example 7, on the other hand, belongs to the category of generic sexiest proverbs. It implies that women are dependent upon men to protect them since they tend to be helpless and subordinate as part of their nature. In the first example, women are associated with the attributes of weak, nä̈ve, and untrusted, whereas they are depicted as weak, dependent and submissive in the second example. The two proverbs reflect the socio-cultural fabric of Iraqi society emphasizing its patriarchal system where women are seen as dependent, subordinate, helpless, second, etc. The following proverbs include physical properties

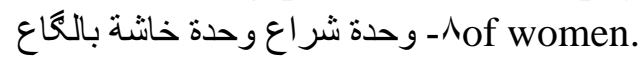

8. (A tall woman is like a sail and a short one is beneath the ground)

$$
\text { 9- الزينة تُّلع و اللاش تتكَبع }
$$

9. (A beautiful woman is to be exposed and an ugly woman is not)

Examples 8 and 9 are generic sexiest proverbs containing physical attributes assigned to women. In these two proverbs, tall and beautiful women are much more liked and preferred by men compared to short and ugly women. Here, women are portrayed as sex objects and personal belongings of men. It seems that the proverbs cited are manly made. It is noted that the attributes of women tend to be of a general sense in that they do not concentrate on a particular part of the woman's body (e.g. the nose, the hair, etc.), rather, the emphasis is on adjectives like 'ugly', 'tall', 'fat', 'thin', etc. Again, this can be due to conservativeness of Iraqi society. It is observed that personal attributes are assigned to the most subcategories of generic and specific categories of women, while physical properties mainly associated with wives and woman in general.

\subsection{Categories of images: Positive vs. negative}

In an attempt to find the kind of image assigned to Iraqi women, connotative meanings associated with nouns and adjectives, verbal choices, implicatures, presuppositions and figures of speech (e.g., metaphors, simile, irony, taboos and hyperbole) are examined. Two main categories of images are identified; positive and negative images. Each of these two images is sub-divided into a number of themes. The negative image includes ten themes including inferiority and weakness, irrationality, stupidity, jealousy, ill-nature, sex object, wickedness, talkativeness, changeability, and ugliness. The positive image, on the other hand, contains five themes including loving and caring, faithfulness, well-organized and sharp-witted person, painstaking and bearability, and beauty and attractiveness. Table 3 below summarizes the distribution of positive and negative images of women in the present data. 
Table 3: Negative image vs. Positive image.

\begin{tabular}{|c|c|c|}
\hline Category of Women & $\begin{array}{l}\text { Positive Themes } \\
\text { (No. \& \%) }\end{array}$ & $\begin{array}{c}\text { Negative Themes } \\
\text { (No. \& \%) }\end{array}$ \\
\hline $\begin{array}{c}\text { Generic Categories of } \\
\text { Women }\end{array}$ & $\begin{array}{c}32 \\
(51.61 \%)\end{array}$ & $\begin{array}{c}150 \\
(59.28 \%)\end{array}$ \\
\hline $\begin{array}{c}\text { Specific Categories of } \\
\text { Women }\end{array}$ & $\begin{array}{c}r \cdot \\
(48.39 \%)\end{array}$ & $\begin{array}{c}1 \cdot r \\
(40.72 \%)\end{array}$ \\
\hline Total & $\begin{array}{c}r r \\
(19.68 \%)\end{array}$ & $\begin{array}{c}253 \\
(80.32 \%)\end{array}$ \\
\hline
\end{tabular}

The statistical results indicate that the distribution of negative portrait or image of woman in Iraqi folk proverbs significantly goes far beyond that of positive image. That is, the distribution of negative image of women represented in the proverbial discourse amounts to $253(80.32 \%$ ) occurrences whereas the distribution of positive image of women constitutes only $62(19.68 \%)$ occurrences. The prevalence of negative representation of women in Iraqi proverbs confirms the well-established notions of gender inequality and masculine hegemony in Iraqi proverbial discourse. This can, in turn, emphasize the patriarchal system of Iraqi society. Likewise, Ambu-Saidi (2010) has found that most of Omani Arabic proverbs refer to women in a negative way. And this negativity is transmitted through generations by referring to women since women in the past are associated with negative tasks and inferior positions compared to men. People in the past believe that negative attributes are not typical of men but of women. The negative and positive images are illustrated in following examples extracted from the present data;

(A woman's mind is not fixed)

$$
\text { عقل مرة كل ساعة براي }
$$

$$
\text { المرة بنص عقلشورو هن وخالفوهن/طاعة النسوان تدخل النار /شور المرة الصايب أيودي بسبع مصايب }
$$

(A woman is half-minded/ Women's obedience leads to hell)

$$
\text { البنت يا تستر ها يا تكَبر ها/ البنية لو لرجلها لو لكَبر ها/هم البنات للممات/ البنت غم ولو مريم }
$$

(A girl is either to get married or to be buried/ A girl is a heavy burden carried on shoulders till death)

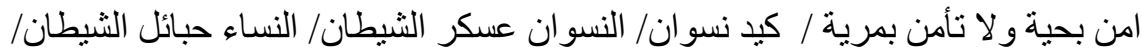

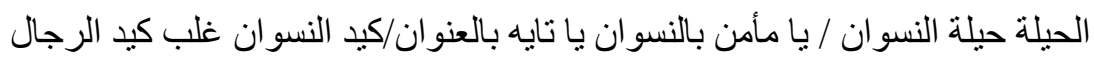

. (Trust a snake but not a woman / Women are so wicked/ Women are devil's soldiers) 


$$
\text { والام اتيتم / الام تلم و الاب يحفر ويطم/ الامة بالبيت ياكل دهن وزيت/ احن من الام على ولدها/ امي يا من دللتني }
$$

(Losing a mother leaves orphans but not a father/ A mother is the kindest person ever/ When a mother in a home, one eats fatty and oily food)

Example 10 shows that women's decisions cannot be taken seriously because women's minds and decisions are not fixed and changeable. Example 11 depicts that women are irrational and their choices and options cannot be fully counted on. Example 12 refers to that women are dependent and weak, and to get rid of them, only two choices are available, mainly, marriage or death. Example 13 indicates that women are vicious and wicked creatures who cannot be fully trusted. All these illustrative examples cited above portray and criticize women severely in a negative way. They entail gender inequality and discrimination. Contrarily, example 14 reveals that mothers are more loving and caring than fathers. As they spend more time in raising children and running family's' affairs, mothers have stronger emotional bonds with their children than fathers. Here, women in general, and mothers in particular are portrayed positively.

It has been said that the sub-category of mothers is mainly described positively and generally associated with positive properties like kindness, loving, caring and bearability. No single proverb describing mothers negatively is found in the present data. This observation can be explained with reference to the socio-religious background of Iraqi people. It is well-documented in the Holy Quran and Prophetic Traditions of the higher status of mothers in building a family and society. As part of their life role, mothers strive to take heavy burdens and great responsibilities on their shoulders to raise their sons and daughters. It is believed that good mothers raise good families and societies and vice versa. Thus, one can say Islam teachings and prescriptions compel Muslims to positively appreciate the role of mother. The following extract is cited from the Prophetic Hadith highlighting the highly-revered position of mothers;

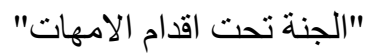

15. (Heaven is at the feet of mothers)

\subsection{Patriarchal discourse in Iraqi folk proverbs}

Cultural ideals of masculinity and femininity are part of gender relations in patriarchal societies (Connell \& Messerschmidt, 2005). "Societies seek to instil gendered values among their individual members. Language, including proverbs, is the main source that creates and maintains patriarchal discourses as it promotes a masculine view of the world at the expense of women, whose version is far less represented in linguistic resources" (Sanauddin, 2015:143). Masculine hegemony has been encoded in Iraqi proverbial discourse through a set of gender stereotypes.

To examine how the proverbial discourse plays a role in the cultural construction of gender roles and relations in Iraqi society, a qualitative content analysis of the texts and 
meanings of individual proverbs is carried out to elicit any patriarchal discourse they may encode. Four cultural themes closely associated with these proverbs are identified, and these are women's comparison to animals, preference for male children, violence against women, and gendered division of work. These themes are based on Walby's (1990) structures of patriarchal system.

Women' behaviors and traits are compared to animals' in the discourse of sample Iraqi proverbs. Women are compared to animals like a cow, bitch, sow, snake, she-ass, mare, locust and cat-fish. All of these animals except for a mare have negative connotations among Iraqi people. Such comparisons belittle and deprecate women's position and roles in the society. Consider the following illustrative proverbs;

(A cow needs water to cover its body)

$$
\text { الجاموسة تريد مي يغطيها }
$$

\section{(A cow needs water to cover its body)}

(As no boys, we call a dog Jasmine)

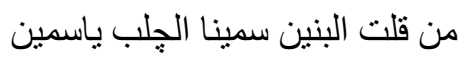

Example 16 embodies the extravagant spending nature of a woman emphasizing that it is the man's responsibility to afford the woman's needs. Example 17 shows that they name a dog by a female' name (i.e., Jasmine) because there is no male children in a family. Indirectly, it boosts and promotes the role of males in Iraqi families stressing male chauvinism. Such proverbs trivialize women and reinforce their subordinate position in the Iraqi society. In the present proverbial data, there are a number of proverbs that assert the preference for male children over female ones. The preference for male children is a common feature of most patriarchal societies. A preference for sons seems to be most widespread in East and South Asia, the Middle East and North Africa (Kapoor, 2014), and Iraq is no exception. The following are some examples from the present data;

$$
\text { البنات للمات/ البنية بلية/ البنات حمل من رمل / ولد مجنون و لا حرة خاتون }
$$

. (Girls are a heavy burden for their parents/ A girl is a big trouble/ An insane boy but not a shrewd girl)

$$
\text { - بيت البنات خالي/ الف عمامة ولا ام خزامة / صوت حية و لا صوت ابنية }
$$

. (A house full of girls is an empty house/A thousand of boys but not a single girl/A snake' hiss is privileged over a girl's voice)

The examples cited above depict the marginalization and subordination of women's status in the Iraqi proverbial discourse. A possible explanation for a boy preference is socio-cultural in nature. It stems from the kinship and descent system and the social status and strength provided to the family by sons (Gupta, 2003). The preference for boys has been documented in the proverbial discourse of Pakistani Pashtuns as well (Sanauddin, 2015).

A sample of Iraqi proverbs encodes a patriarchal discourse, and plays a role in upholding patriarchy through the use of violence against women. Men's violence against women is an essential part of patriarchy and hegemonic masculinity (Walby, 1990). Gender-based violence against women in Iraqi proverbs takes many different forms, but 
the most common form is wife-beating and fearing. Consider the following illustrative examples;

$$
\begin{aligned}
& \text { ـ ـ اضرب المرة قبل الغدة وبعد العشة/ المتهاب من و اليها متهاب من الجيران / }
\end{aligned}
$$

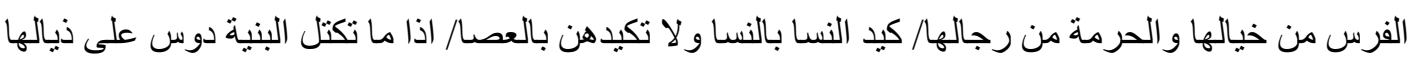

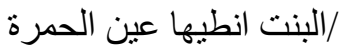

- (Beat a woman before lunch and after dinner/ A woman with no fear of her husband has no fear of her neighbors/A mare is known by its horseman and a woman by her husband/ Let women deceit women and do not deceit them by a stick)

The examples quoted above emphasize the ideal of masculinity which is realized through the use of threat or actual use of force to discipline women of the household. Wife beating and threatening are the due right of men. It is important to observe that in "violence-related proverbs, men are always the subject and women have never been portrayed as active subjects; they are the object of violence" (Sanauddin, 2015:150).

In spite of an increasing access of education and work for Iraqi women nowadays, the discourse of Iraqi proverbs depicts an exclusionary picture of gendered division of work where women's primary role is inside the home, and household affairs are often cherished. The following are some examples from the present data;

$$
\text { ـ المرة مكانها بيتها/ جد المرة ما بيه ثمرة/ جد المرة للكزبرة/ منك المال ومنها البنين }
$$

. (A woman's place is her home/A woman's work is worthless and devalued / A man brings money and a women gives birth to sons)

Examples above endorse hegemonic masculinity according to which earning and providing for the family members are the ideal role of males but not females. Females are unable to perform the ideal masculine role of earning money; instead homes are their natural place.

\section{. Conclusions}

So far it has been examined the stereotypical representation of women and their position in the discourse practices of Iraqi folk proverbs from a feminist stylistics perspective. Proverbs are considered as the essence of language and a mirror of reality, so they can reflect people's values, attitudes, practices and systems of their society. They continue to present stereotyped masculinity and femininity despite contemporary changes in gender roles.

As far as the category of women most frequently targeted in Iraqi proverbs is concerned, the category of woman in general is more depicted than the specific one. More precisely, the sub-category of generic woman is the most salient target of sexiest proverbs whereas wives tend to be the most dominant target within the specific category of sexiest proverbs. As to the most salient attributes associated with women in Iraqi folk proverbs, personal attributes are more frequently used than physical ones to portrait Iraqi women. With reference to the kind of woman's image represented in the proverbial 
discourse, women are far more depicted negatively than positively. The discourse of Iraqi folk proverbs is generally manipulated to disparage women in general. It has been found that the discourse of Iraqi proverbs encodes the traditional ideals of hegemonic masculinity, patriarchal ideology and gender inequality. Women are seen as subordinate and marginal, and their role falls within a private sphere (i.e., their homes). Social practices and gender stereotypes like a preference for sons over daughters, violence against women, and gendered division of work promote such a sexiest tendency in the discourse of proverbs. The institutionalization of male domination and the secondary position of women are grounded in the structural system of Iraqi society.

\section{References}

Al-Dabag, A. (1956). A collection of Musli proverbs. Musl: Hadif Press.

Al-Hanefi, J. (1962). Baghdadi proverbs. Baghdad: Asaad Press.

Al-Tikriti, A. (1986). An encyclopedia of Baghdadi proverbs. Baghdad: Irshad Press.

Al-Dileishi, A. (1972). Folk Basrain proverbs. Baghdad: Shafiq Press.

Ambu-Saidi, S. (2010). A gender and language analysis of Omani proverbs. Unpublished Master's Thesis. University of Florida.

Andersson, D. (2012). Gender-related proverbs in a peasant society in Northern Sweden. Journal of Northern Studies, 6 (2), 9-36.

Asimeng-Boahene, L. (2013). The Social construction of Sub-Saharan women's status through African proverbs, Mediterranean Journal of Social Sciences, 4 (1), 123-131.

Basow, S. (1992). Gender stereotypes and roles. Pacific Grove: Brooks/Cole.

Belfatmi, F. (2013). The representation of women in Moroccan proverbs. Journal of Humanities and Social Science, 17(1),15-21.

Bemiller, M. \& Schneider, R. (2010). It's not just a joke. Sociological Spectrum, 30 (4), 459-479.

Cameron, D. (2008). The myth of Mars and Venus: Do men and women really speak different languages? Oxford: Oxford University Press.

Connell, R. \& Messerschmidt, J. (2005). Hegemonic masculinity: Rethinking the concept. Gender \& Society, 19 (6), 829-859.

El-Falaky, M. (2015). The representation of women in street songs: A critical discourse analysis of Egyptian Mahraganat. Advances in Language and Literary Studies, 6 (5), 1-8.

Fairclough, N. (1992). Discourse and social change. Cambridge: Polity Press.

Fairclough, N. (1989). Language and Power. London : Longman.

Fowler, R. (1991). Language in the news: Discourse and ideology in the press. New York: Routledge.

Gupta, M. (2003). Why is son preference so persistent in East and South Asia? A crosscountry study of China, India and the Republic of Korea. The Journal of Development Studies, 40 (2), 153-187. 
Hussein, J. (2009). A discursive representation of women in sample proverbs from Ethiopia, Sudan, and Kenya. Research in African Literatures, 40 (3), 96 108.

Kapoor, S. (2014). Negotiating with patriarchy: Gender and childhood in India. In Cultural realities of being: Abstract ideas within everyday lives. Edited by Nandita Chaudhary, pp.49-68. Sussex, Routledge.

Kerschen, L. (2012). American Proverbs about Women. Connecticut: Greenwood Press. Lee, J. (2015). Chinese proverbs: How are women and men represented? Multidisciplinary Journal of Gender Studies, 4(1), 559-585.

Marco , L. (1997). Linguistic choices for the representation of women in discourse. Barcelona English Language and Literature Studies, 8, 247-259.

Mills, S. (2008). Language and sexism. Cambridge: Cambridge University Press. Mills, S. (1995). Feminist stylistics. London: Routledge.

Nakhavaly, F. \& Sharifi, S. (2013). On sex discrimination in Persian proverbs. Theory and Practice in Language Studies, 3 (1), 195-200.

Nayef, H. \& EL-Nashar, M. (2015). Indirect sexism: Linguistic representation of women in Egyptian print media. International Journal of Linguistics and Communication, 3(2), 164-175.

Nayef, H. \& EL-Nashar, M. (2014). Promoting masculine hegemony through humour: A linguistic analysis of gender stereotyping in Egyptian sexist internet jokes. International Journal of Linguistics and Communication, 2 (4), 69-84.

Paltridge, B. (1994). Genre analysis and the identification of textual boundaries. Applied Linguistics, 15 (3), 288-299.

Reutler, M. (2013). How gender stereotypes are achieved linguistically in AMC's mad men. Journal of Serial Narration on Television, 2,73-85.

Sadiqi, F. (2003). Woman, gender and language in Morocco. Leiden, The Netherlands: Brill.

Sanauddin, N. (2015). Proverbs and patriarchy: analysis of linguistic sexism and gender relations among the Pashtuns of Pakistan. Unpublished PhD thesis. University of Glasgow.

Stone, J. (2006). The Routledge book of world proverbs. New York: Routledge.

Sunderland, J. (2007). Language and gender. London: Routledge.

Talbot, M. (2010). Gender stereotypes: Reproduction and challenge. In: The handbook of language and gender. Edited by J. Holmes \& M. Meyerhoff, pp.468486. Malden: Blackwell Publishing. 
Van Dijk, T. (2001). Critical discourse analysis. In Handbook of discourse analysis. Edited by D. Tannen, D. Schiffrin, \& H. Hamilton,pp. 130-156. Oxford, Blackwell.

Walby, S. (1990). Theorizing patriarchy. Oxford: Blackwell Publishing. 